\title{
CO Reactivity of Manganese Lumps Versus Briquettes
}

\author{
Leandro Gustavo Mendes DE JESUS ${ }^{1) *}$ and Merete TANGSTAD ${ }^{2)}$ \\ 1) Federal Institute of Education Science and Technology of Mato Grosso do Sul, Department of Metallurgy, Corumbá, 79310 - \\ 110 Brazil. \\ 2) Norwegian University of Science and Technology/Department of Materials Science and Engineering, Trondheim, 7034 \\ Norway.
}

(Received on August 15, 2019; accepted on February 18, 2020)

\begin{abstract}
In this work, a comparison between $\mathrm{CO}$ reactivity of lumps and briquettes made of two different binder and three different raw materials is presented. Experimental results on the prereduction behavior of such materials in $70 \% \mathrm{CO}$ and $30 \% \mathrm{CO}_{2}$ atmosphere, heating rate of $0,17 \mathrm{~K} / \mathrm{s}\left(10^{\circ} \mathrm{C} / \mathrm{min}\right)$ at temperatures up to $1100^{\circ} \mathrm{C}$ are discussed. It was shown that briquettes presented higher CO reactivity, especially those whose molasses was the binder which had the highest reactivity. Level of oxygen also played an important role in CO reactivity. Comilog and Urucum with the highest oxygen level had highest reactivity while Assmang with the lowest oxygen level had the lowest reactivity between the raw materials. Porosity was a key variable to explain $\mathrm{CO}$ reactivity. Molasses briquettes had the highest porosity and the highest $\mathrm{CO}$ reactivity followed by bentonite briquettes and lumps.
\end{abstract}

KEY WORDS: manganese ore fines; pre-reduction; briquettes; CO reactivity.

\section{Introduction}

During mining and mineral processing of manganese ore between 30 and $60 \%$ of the material extracted from the mine is treated as waste. ${ }^{1)}$ Even though such materials have similar chemical composition as the manganese ferroalloy producers require, they are much finer than what is acceptable in submerged arc furnaces. Despite being challenging, to improve the usage of fines in the furnace could be interesting, both economically and environmentally. It would lower the amount of tailings and increase the usage of the reservoir. Agglomeration processes were designed as a solution to enhance the usage of fines in metallurgical processes. Briquetting stands as a low investment and operational costs and would be one of the interesting agglomeration techniques reducing the waste material.

When the manganese materials are charged into the furnace, it is desired that higher manganese oxides are reduced in the solid state to $\mathrm{MnO}$ at temperatures lower than $800^{\circ} \mathrm{C}$, as it is believed that the undesirable Boudouard reaction starts around this temperature. During the reduction processes the unstable higher manganese oxides $\mathrm{MnO}_{2}, \mathrm{Mn}_{2} \mathrm{O}_{3}$, $\mathrm{Mn}_{3} \mathrm{O}_{4}$ will be reduced with $\mathrm{CO}$ gas. Hence, the manganese oxide, $\mathrm{MnO}_{\mathrm{x}}$ will be reduced to $\mathrm{MnO}$, where the $\mathrm{x}$ ranges from 2 down to 1 . The reduction reactions are reduced by the following reactions: ${ }^{1)}$

$$
\begin{aligned}
& \mathrm{MnO}_{2}+1 / 2 \mathrm{CO}=1 / 2 \mathrm{Mn}_{2} \mathrm{O}_{3}+1 / 2 \mathrm{CO}_{2} \\
& \Delta \mathrm{H}^{0}=-99,9 \mathrm{~kJ} \cdot \mathrm{mol}^{-1} \\
& 1 / 2 \mathrm{Mn}_{2} \mathrm{O}_{3}+1 / 6 \mathrm{CO}=1 / 3 \mathrm{Mn}_{3} \mathrm{O}_{4}+1 / 6 \mathrm{CO}_{2} \\
& \Delta \mathrm{H}^{0}=-31,3 \mathrm{~kJ} \cdot \mathrm{mol}^{-1} \\
& 1 / 3 \mathrm{Mn}_{3} \mathrm{O}_{4}+1 / 3 \mathrm{CO}=\mathrm{MnO}+1 / 2 \mathrm{CO}_{2} \\
& \Delta \mathrm{H}^{0}=-16,9 \mathrm{~kJ} \cdot \mathrm{mol}^{-1}
\end{aligned}
$$

Ideally, the heat produced by the electric current flowing through the cokebed zone promotes reduction of $\mathrm{MnO}$ to manganese metal releasing $\mathrm{CO}$ at high temperatures $\left(1400-1600^{\circ} \mathrm{C}\right)$. The ascending $\mathrm{CO}$ gas heats the charge promoting the mentioned reactions.

However, if the pre-reduction is not finished before the charge temperature reaches $800^{\circ} \mathrm{C}$, the reaction path will be different as shown in the following:

$$
\begin{gathered}
1 / 3 \mathrm{Mn}_{3} \mathrm{O}_{4}+1 / 3 \mathrm{CO}=\mathrm{MnO}+1 / 2 \mathrm{CO}_{2} \\
\Delta \mathrm{H}^{0}=-16,9 \mathrm{~kJ} \cdot \mathrm{mol}^{-1} \\
1 / 3 \mathrm{C}+1 / 3 \mathrm{CO}_{2}=2 / 3 \mathrm{CO} \\
\Delta \mathrm{H}^{0}=+57,5 \mathrm{~kJ} \cdot \mathrm{mol}^{-1}
\end{gathered}
$$

\footnotetext{
* Corresponding author: E-mail: leandro.mendes@ifms.edu.br
} 


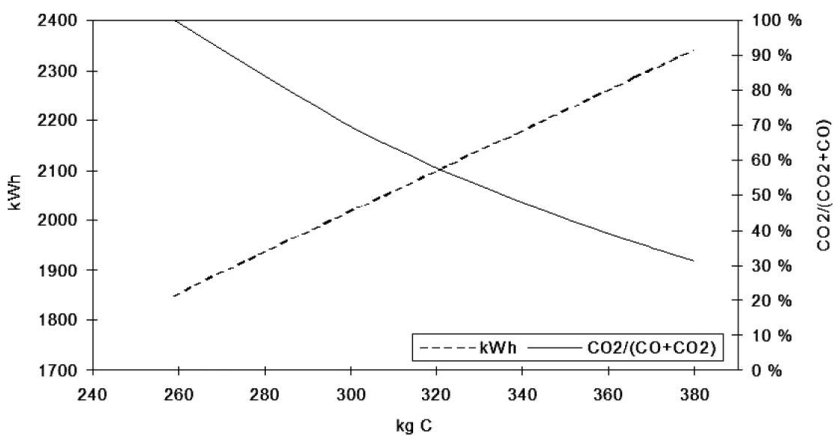

Fig. 1. The relation between coke consumption, the $\mathrm{CO}_{2} /$ $\left(\mathrm{CO}+\mathrm{CO}_{2}\right)$ ratio and the consumption of electric energy for production of $\mathrm{HCFeMn}$ from a random charge. ${ }^{2)}$

$$
\begin{aligned}
& 1 / 3 \mathrm{Mn}_{3} \mathrm{O}_{4}+1 / 3 \mathrm{C}=\mathrm{MnO}+1 / 3 \mathrm{CO} \\
& \Delta \mathrm{H}^{0}=+40,6 \mathrm{~kJ} \cdot \mathrm{mol}^{-1}
\end{aligned}
$$

The pre-reduction will be carried out through the Boudouard reaction which is highly endothermic. Thus, there will be an increase of the coke consumption and a higher demand of electrical energy.

The degree of pre-reduction defined by Tangstad ${ }^{2)}$ is expressed by the off-gas ratio $\left(\mathrm{CO}_{2}\right) /\left(\mathrm{CO}_{2}+\mathrm{CO}\right)$ and is directly related to the coke and energy consumption as showed in Fig. 1 for a fixed charge. The lowest the ratio the highest the degree of pre-reduction.

In this paper, the degree of pre-reduction, which is also the $\mathrm{CO}$ reactivity, of briquettes made of three different manganese raw materials and two different binders will be measured and compared with lumps of the same materials. As stated by Turkova et al. ${ }^{3)}$ the CO reactivity was defined as the ability of manganese materials to be reduced to $\mathrm{MnO}$ by $\mathrm{CO}$ gas in a temperature range from $0^{\circ} \mathrm{C}$ to $800^{\circ} \mathrm{C}$. The porosity of the materials will also be measured to see its effect on the $\mathrm{CO}$ reactivity.

\section{Apparatus and Procedures}

\subsection{Materials}

The manganese materials used in this paper were Comilog ore from Gabon and Assmang ore from South Africa in form of lumps. Urucum tailing dam's material was collected in the city of Corumbá in Brazil and was provided as fines.

The lumpy material was $9-15 \mathrm{~mm}$ particles. In order to produce briquettes, the lumpy ores (Comilog and Assmang) materials were first crushed and sieved. The Urucum material was also sieved. All materials used in the briquettes was $-250 \mu \mathrm{m}$. The size distribution of the raw materials is shown in Table 1.

The materials were chemical analyzed by X-ray fluorescence while the $\mathrm{MnO}_{2}$ amount was obtained by titration. Table 2 shows the chemical analysis of the raw materials.

The materials were chemical analyzed by X-ray fluorescence while the $\mathrm{MnO}_{2}$ amount was obtained by titration. Table 2 shows the chemical analysis of the raw materials.

As binders, two different materials were used, molasses and bentonite. Molasses is a byproduct of the sugar cane refining and has a very wide composition. The main components are carbohydrates and water. ${ }^{4)}$ Bentonite is
Table 1. Briquette's raw material size distribution.

\begin{tabular}{cccccc}
\hline \multirow{2}{*}{ Raw material } & \multicolumn{5}{c}{ Retained [\%] } \\
\cline { 2 - 6 } & $250 \mu \mathrm{m}$ & $100 \mu \mathrm{m}$ & $63 \mu \mathrm{m}$ & $45 \mu \mathrm{m}$ & $0 \mu \mathrm{m}$ \\
\hline Comilog & 0,00 & 48,35 & 71,65 & 82,59 & 100,00 \\
Assmang & 0,00 & 37,79 & 50,78 & 58,33 & 100,00 \\
Urucum & 0,00 & 67,96 & 81,71 & 88,28 & 100,00 \\
\hline
\end{tabular}

Table 2. Raw materials chemical composition, mass $\%$ ( $L=$ lumpy ore, $\mathrm{B}=$ briquettes, analyzed by SINTEF Molab).

\begin{tabular}{ccccccc}
\hline \multirow{2}{*}{ Compound } & \multicolumn{2}{c}{ Comilog } & \multicolumn{2}{c}{ Assmang } & \multicolumn{2}{c}{ Urucum } \\
\cline { 2 - 7 } & \multicolumn{1}{c}{$\mathrm{L}$} & $\mathrm{Bq}$ & $\mathrm{L}$ & $\mathrm{Bq}$ & $\mathrm{L}$ & $\mathrm{Bq}$ \\
\hline $\mathrm{Mn}_{\text {tot }}$ & 48,08 & 46,15 & 46,87 & 45,05 & 42,22 & 27,28 \\
$\mathrm{MnO}_{2}$ & 71,35 & 66,16 & 34,91 & 33,70 & 62,13 & 40,43 \\
$\mathrm{Fe}_{\text {tot }}$ & 6,62 & 3,56 & 7,52 & 9,63 & 15,69 & 28,16 \\
$\mathrm{SiO}_{2}$ & 2,93 & 6,53 & 4,11 & 5,65 & 1,70 & 9,11 \\
$\mathrm{Al}_{2} \mathrm{O}_{3}$ & 5,05 & 8,12 & 0,46 & 0,45 & 1,28 & 2,93 \\
$\mathrm{CaO}$ & 0,08 & 0,40 & 8,25 & 7,60 & 0,17 & 0,20 \\
$\mathrm{MgO}$ & 0,10 & 0,11 & 1,82 & 1,15 & 0,14 & 0,10 \\
$\mathrm{TiO}_{2}$ & 0,13 & 0,21 & 0,01 & 0,02 & 0,09 & 0,21 \\
$\mathrm{P}$ & 0,18 & 0,17 & 0,05 & 0,03 & 0,15 & 0,25 \\
$\mathrm{~S}$ & 0,02 & 0,01 & 0,06 & 0,33 & 0,05 & 0,04 \\
$\mathrm{~K}_{2} \mathrm{O}$ & 0,90 & 1,00 & 0,04 & 0,01 & 3,32 & 1,73 \\
$\mathrm{BaO}$ & 0,18 & 0,23 & 0,17 & 0,93 & 0,21 & 0,29 \\
$\mathrm{H}_{2} \mathrm{O}$ & 0,39 & 0,62 & 0,00 & 0,04 & 0,00 & 0,00 \\
\hline
\end{tabular}

a clay mineral which consists mostly of montmorillonite with chemical formula of $(\mathrm{Na}, \mathrm{Ca})_{0,33}(\mathrm{Al}, \mathrm{Mg})_{2}\left(\mathrm{Si}_{4} \mathrm{O}_{10}\right)(\mathrm{OH})_{2}$. $\mathrm{nH}_{2} \mathrm{O}$. ${ }^{5)}$ The molasses briquettes were made with the mass percentage of $10 \%$ of binder while the bentonite briquettes had a mass percentage of $5 \%$. Results obtained by $B y^{6)}$ were used to set the binder content.

\subsection{Production of the Briquettes}

The raw materials were mixed for 2 minutes and the mixture was pressed by the use of an axial press, a stainlesssteel die and a punch of $10 \mathrm{~mm}$ of inner diameter with a pressure of $100 \mathrm{MPa}$. After the pressure in the axial press was reached, it was kept for 30 seconds before the briquette was released.

\subsection{Apparatus and Test Description}

The CO reactivity test was performed in a thermogravimetric furnace. Figure 2 shows a picture of the furnace and a diagram of the crucible. The crucible was charged with around $100 \mathrm{~g}$ of materials as briquettes or lumpy ore.

The $\mathrm{CO}$ reactivity test consisted of heating the sample with a heating rate of about $0,17 \mathrm{~K} / \mathrm{s}\left(10^{\circ} \mathrm{C} / \mathrm{min}\right)$ for 110 minutes, finishing the test at $1100^{\circ} \mathrm{C}$. The furnace heating and heating rate is controlled by a thermocouple located on the furnace wall. There is also a thermocouple recording the temperature within the crucible, since the reactions can absorb or release heat causing deviations between the furnace temperature and the crucible temperature.

During the heating of the sample a gas mixture consisting of $70 \% \mathrm{CO}$ and $30 \% \mathrm{CO}_{2}$ was charged inside the crucible, the gas mixture flowrate was $6,67.10^{-5} \mathrm{~m}^{3} / \mathrm{s}$ (4 Nlpm). The gas is heated in the double walled crucible and will hence 


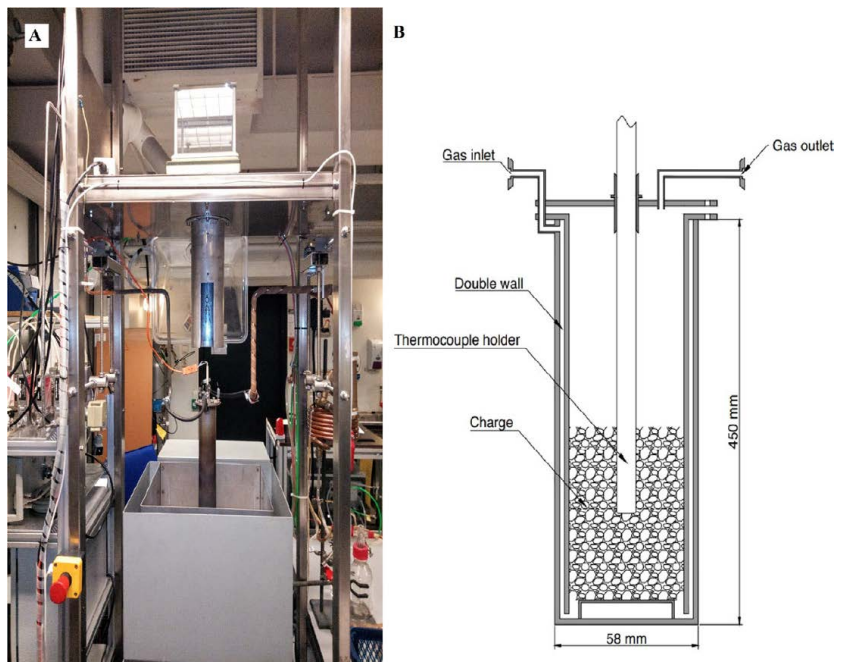

Fig. 2. Retort thermogravimetric furnace (A) and a diagram of its crucible (not to scale, B). (Online version in color.)

have a high temperature when seeing the material. When the test was finished, the furnace power was turned off and argon was flushed at a flowrate of $1,67.10^{-5} \mathrm{~m}^{3} / \mathrm{s}(1 \mathrm{Nlpm})$ for 45 minutes to quench the sample and avoid re-oxidation of the sample.

\subsection{Porosity Tests}

Before and after the $\mathrm{CO}$ reactivity tests were performed, three briquettes/lumps were sampled, and their porosity was assessed. The porosity was measured by the ratio between the envelope volume and the pore volume. The envelope volume test was performed by a GeoPyc 1360 pycnometer. The pore volume was taken by an AccuPyc 1330 helium pycnometer.

\section{Results and Discussion}

The measured parameters obtained during experiment is showed by Fig. 3. Crucible temperature, furnace temperature, mass loss, $\mathrm{CO}$ and $\mathrm{CO}_{2}$ content in the off-gas are plotted. In addition, the mass before and after the experiment is measured. In order to obtain the $\mathrm{MnO}_{\mathrm{x}}$ versus temperature some assumptions were made. For instance, in the comparison between lumpy ore with molasses briquettes, it is not possible to convert the mass, and its loss, into $\mathrm{MnO}_{\mathrm{x}}$ directly, since molasses is evaporated and shift the final mass loss as well as the mass loss behavior. Therefore, to neutralize such effects the $\mathrm{CO}_{2}$ function in the off-gas, $\mathrm{g}(\mathrm{t})$, was used to determine the $\mathrm{x}$ from the $\mathrm{MnO}_{\mathrm{x}}$ behavior as function of temperature. Assuming that all manganese ore reduction will result into a higher $\mathrm{CO}_{2}$ concentration in the off-gas it is possible to relate these data with the reaction course.

Thus, the instant $\mathrm{x}$ values, $\mathrm{x}_{\mathrm{i}}$, from the $\mathrm{MnO}_{\mathrm{x}}$ were calculated by the $\mathrm{CO}_{2}$ in the gas analysis. The $\mathrm{x}$ value is ranging from the initial $x$ value, $x_{0}$, to the final $x$ value, $x_{f}$ which are obtained by the chemical analysis. The behavior of the curve was given by the rate between the amount of gas generated up to the moment, $\mathrm{g}\left(\mathrm{t}_{\mathrm{i}}\right)$, and the total amount of gas released, $\mathrm{g}\left(\mathrm{t}_{\mathrm{f}}\right)$. The mathematical expression is given by:

$$
\mathrm{x}_{\mathrm{i}}=\left(1-\frac{\mathrm{g}\left(\mathrm{t}_{\mathrm{i}}\right)}{\mathrm{g}\left(\mathrm{t}_{\mathrm{f}}\right)}\right) \cdot\left(\mathrm{x}_{0}-\mathrm{x}_{\mathrm{f}}\right)+\mathrm{x}_{\mathrm{f}}
$$

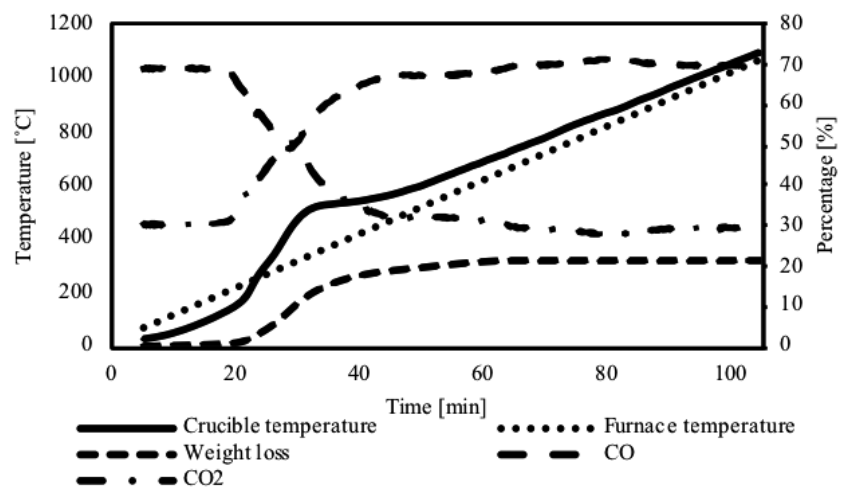

Fig. 3. Typical raw data obtained by a test in the furnace with Comilog and molasses briquettes.

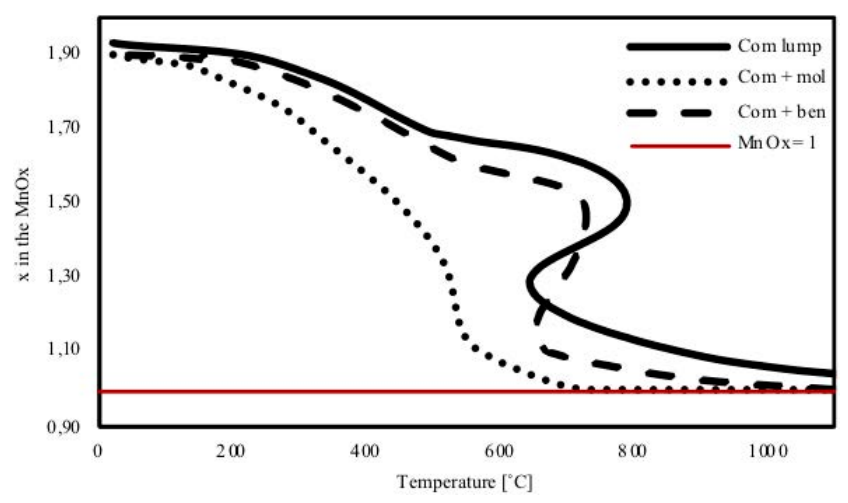

Fig. 4. The calculated $\mathrm{MnO}_{x}$ of Comilog materials. (Online version in color.)

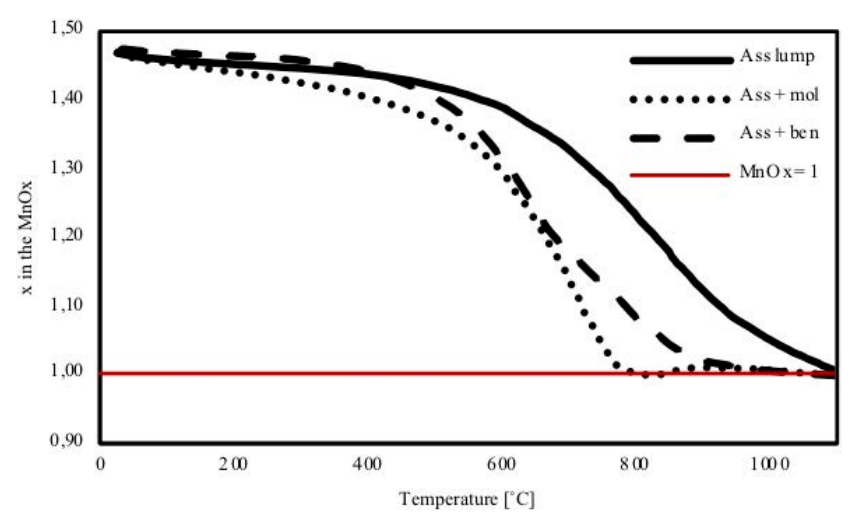

Fig. 5. The calculated $\mathrm{MnO}_{\mathrm{x}}$ of Assmang materials. (Online version in color.)

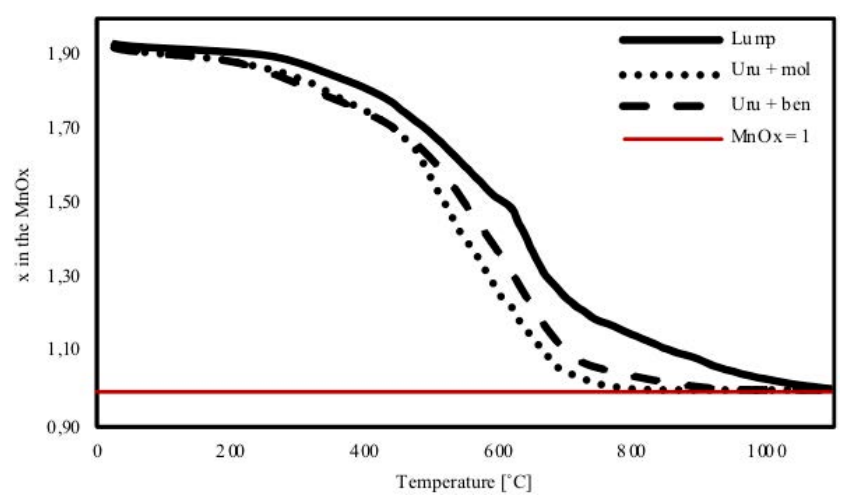

Fig. 6. The calculated $\mathrm{MnO}_{\mathrm{x}}$ of Urucum materials. (Online version in color.) 
Figures 4 to 6 show the $\mathrm{x}$ in the $\mathrm{MnO}_{\mathrm{x}}$ versus crucible temperature. It can be seen that when the temperature increases the reduction proceeds. The further increase on the temperature within the crucible due to the exothermic reactions can also be noticed. This effect is noticed in higher extent in Comilog samples due to higher oxygen levels (Fig. 4). It was not possible to distinguish the different oxides reduction as there is a continuous mass loss, which was previously observed by other authors. ${ }^{7-9)}$ In addition, the reduction behavior of briquettes in comparison with lumps reveal that agglomerates behaved as fines where the reaction started at lower temperatures as previously observed by Welham. ${ }^{10)}$

It can also be seen that for briquettes with molasses, at $800^{\circ} \mathrm{C}$ the reduction is finished. This is not the case for bentonite briquettes nor lumpy material. Comilog lumps was not reduced completely to $\mathrm{MnO}$ even after it reached $1100^{\circ} \mathrm{C}$.

Table 3 shows the calculated $\mathrm{MnO}_{\mathrm{x}}$, at $800^{\circ} \mathrm{C}$. The chemical composition of the materials after the experiments is shown in Table 4. It can be noticed from Figs. 4-6 that briquettes and lumps of all the raw materials with the exception of Comilog have been reduced to $\mathrm{MnO}$ at the end of the experiment. Despite the reduction path of the different raw materials are different, the $\mathrm{CO}$ reactivity of molasses briquettes is similar, since all the materials were completely reduced to $\mathrm{MnO}$ at $800^{\circ} \mathrm{C}$. The bentonite briquettes also behave similarly, as they reached similar $\mathrm{x}$ values at $800^{\circ} \mathrm{C}$ between 1.02 to 1.05 .

Comilog and Urucum lumpy ore at $800^{\circ} \mathrm{C}$ has relatively similar CO reactivity. The amount of oxygen left in the ore is 1,14 in Comilog and 1,15 in Urucum. The high $\mathrm{x}$ values in its initial composition, 1,94 and 1,92 respectively, indicates that these two raw materials are mainly composed by $\mathrm{MnO}_{2}$ and at $800^{\circ} \mathrm{C}$ the reduction is somewhere between the $\mathrm{Mn}_{3} \mathrm{O}_{4}(\mathrm{x}=1,33)$ and $\mathrm{MnO}(\mathrm{x}=1,00)$ at $800^{\circ} \mathrm{C}$. However, when the test was finished only Urucum raw material was completely reduced while Comilog was mostly reduced. Assmang lumpy material started with $\mathrm{x}=1,47$ corresponding to a $\mathrm{Mn}_{2} \mathrm{O}_{3}$ composition. At $800^{\circ} \mathrm{C}$ it's the oxygen level was somewhere between $\mathrm{Mn}_{3} \mathrm{O}_{4}$ and $\mathrm{MnO}$.

The $\mathrm{MnO}_{\mathrm{x}}$ versus temperature for Comilog lumpy ore has a high increase of temperature, followed for a smaller temperature increase in lumpy Urucum. This is explained

Table 3. Calculated $\mathrm{MnOx}$ of materials at $800^{\circ} \mathrm{C}$.

\begin{tabular}{|c|c|c|c|c|c|c|c|c|c|}
\hline \multirow{2}{*}{ Compound } & \multicolumn{3}{|c|}{ Comilog } & \multicolumn{3}{|c|}{ Assmang } & \multicolumn{3}{|c|}{ Urucum } \\
\hline & $\mathrm{L}$ & M & B & $\mathrm{L}$ & M & B & $\mathrm{L}$ & M & B \\
\hline $\mathrm{MnO}_{\mathrm{x}}$ & 1,14 & 1 & 1,05 & 1.23 & 1 & 1,05 & 1,15 & 1 & 1,02 \\
\hline
\end{tabular}

Table 4. Chemical composition of materials after CO reactivity tests at $1100^{\circ} \mathrm{C}, \operatorname{mass} \%$.

\begin{tabular}{|c|c|c|c|c|c|c|c|c|c|}
\hline \multirow{2}{*}{ Compound } & \multicolumn{3}{|c|}{ Comilog } & \multicolumn{3}{|c|}{ Assmang } & \multicolumn{3}{|c|}{ Urucum } \\
\hline & $\mathrm{L}$ & M & B & $\mathrm{L}$ & $\mathrm{M}$ & B & $\mathrm{L}$ & $\mathrm{M}$ & B \\
\hline $\mathrm{Mn}_{\text {tot }}$ & 67,25 & 50,79 & 53,72 & 57,14 & 51,54 & 53,37 & 56,54 & 31,71 & 30,29 \\
\hline $\mathrm{MnO}_{2}$ & 4,77 & $<0,05$ & $<0,05$ & $<0,05$ & $<0,05$ & $<0,05$ & $<0,05$ & $<0,05$ & $<0,05$ \\
\hline $\mathrm{Fe}_{\text {tot }}$ & 1,83 & 10,96 & 4,36 & 8,70 & 11,01 & 8,64 & 9,95 & 32,39 & 30,60 \\
\hline
\end{tabular}

by the high amount of $\mathrm{MnO}_{2}$ in the ore and consequent high release of heat due to the exothermic prereduction reactions, reaction (1). Comilog and Urucum briquettes did not present the same effect due to its particle size. Even though the briquettes were agglomerated to bigger sizes it seems that during reduction they behaved as fines which resulted in lower increase in temperature as observed by Pochart et al. ${ }^{11)}$ This is due to the fact that the reduction of $\mathrm{MnO}_{2}$ starts sooner and will hence be reduced over longer time. As Assmang ore has lower initial oxygen content, that is $\mathrm{Mn}_{2} \mathrm{O}_{3}$, the same heating was not present. Such trend between Comilog and Assmang ore reactivities was already observed by Berg and Olsen. ${ }^{12}$

The raw materials with the higher oxygen content presented a higher reactivity and the same trend was observed by other authors. ${ }^{3,7,8,10,13-15)}$ Thus, Urucum ore and Comilog ore have higher reactivity than Assmang ore. In general, the $\mathrm{CO}$ reactivity can also be ranked by the form of the material that is being reduced from the highest to the lowest, as following: molasses briquettes, bentonite briquettes and lumpy ore.

As it was previous mentioned, the excess of oxygen that remains after $800^{\circ} \mathrm{C}$ will not be reduced by $\mathrm{CO}$ gas. This means that it is considered that any oxygen excess, other than $\mathrm{x}=1$, will reduce through the carbon gasification, Reaction 5. Such assumption means a higher carbon consumption for materials that were not completely prereduced to $\mathrm{MnO}$ at $800^{\circ} \mathrm{C}$. Table 5 shows the additional carbon consumption that every material would require.

Despite Comilog and Urucum lumps starts with a higher oxygen content their high reactivity leads to lower carbon consumption. Assmang lumps is hence the material with the lowest reactivity and will hence consume more carbon. The briquettes made with molasses as binder are completely prereduced at $800^{\circ} \mathrm{C}$, hence, they do not demand any additional carbon material. These ores also release high amount of energy during the pre-reduction due to exothermic reactions. The bentonite briquettes have similar behavior as the molasses briquettes but with lower reactivity demanding lower additional carbon than lumps. It can clearly be noticed that briquettes have higher reactivity and the binder will determine the $\mathrm{CO}$ reactivity more than the difference between the ores.

Table 5. Additional carbon consumption per ton of manganese in the raw material for reduction above of higher manganese oxides in Boudouard reaction active zone.

\begin{tabular}{lccc}
\hline Material & Type & $\begin{array}{c}\mathrm{MnO}_{\mathrm{x}} \text { value } \\
\text { at } 800^{\circ} \mathrm{C}\end{array}$ & $\begin{array}{c}\text { Carbon, } \\
\mathrm{kg} / \text { ton of } \mathrm{Mn}\end{array}$ \\
\hline Comilog & $\mathrm{L}$ & 1,14 & 249,4 \\
& $\mathrm{M}$ & 1,00 & 218 \\
& $\mathrm{~B}$ & 1,05 & 229,3 \\
\hline \multirow{3}{*}{ Assmang } & $\mathrm{L}$ & 1,23 & 268,6 \\
& $\mathrm{M}$ & 1,00 & 218 \\
& $\mathrm{~B}$ & 1,05 & 229,3 \\
\hline \multirow{3}{*}{ Urucum } & $\mathrm{L}$ & 1,15 & 251,2 \\
& $\mathrm{M}$ & 1,00 & 218 \\
& $\mathrm{~B}$ & 1,02 & 222,8 \\
\hline
\end{tabular}


It is possible to conclude, from the point of view of the manganese ferroalloys industrial process, that briquettes made with molasses as binder will provide the most beneficial effect on carbon and energy consumption. Such favorable effect occurs mainly in the Comilog and Urucum briquettes, since they will not demand additional carbon consumption and also that their high amount of oxygen result in high energy release. The use of bentonite as binder reduces the performance of the briquettes raising the carbon consumption. Furthermore, the use of lumpy material would cause a negative effect, since they have shown relatively low $\mathrm{CO}$ reactivity, thus, the highest carbon consumption. Among the lumpy materials, Assmang performed with the lowest $\mathrm{CO}$ reactivity, consequently, has the highest theoretical carbon consumption. The lowering in coke consumption and energetical advantages of the usage of agglomerates was already pointed in other studies. $3,13,14,16$ )

The porosity tests of the sampled briquettes specimens and lump particles are shown in Table 6. In order to compare the porosity of the different raw materials, the mean values between three measurements were used. The porosity of molasses briquettes was considered to be the tested sample porosity, since their green porosity was very low due to the molasses which spread through the pores and voids between the agglomerate particles. However, as studied by Flores et al. ${ }^{17)}$ molasses is decomposed at around $200^{\circ} \mathrm{C}$. Hence, it is assumed that additional porosity, mentioned by Turkova, ${ }^{3)}$ created by removal of bound water, $\mathrm{CO}_{2}$ from carbonates and reduction of manganese oxides was negligible when compared with the porosity left by the molasses

Table 6. Porosity tests results ( $\mathrm{L}, \mathrm{B}$ is green porosity, M is tested sample porosity).

\begin{tabular}{ccc}
\hline Material & Type & Porosity [\%] \\
\hline \multirow{3}{*}{ Comilog } & L & 22,5 \\
& M & 45,2 \\
& B & 28,3 \\
\hline \multirow{2}{*}{ Assmang } & L & 5,3 \\
& M & 39,4 \\
& B & 20,9 \\
\hline \multirow{2}{*}{ Urucum } & L & 17,5 \\
& M & 34,7 \\
& B & 28 \\
\hline
\end{tabular}

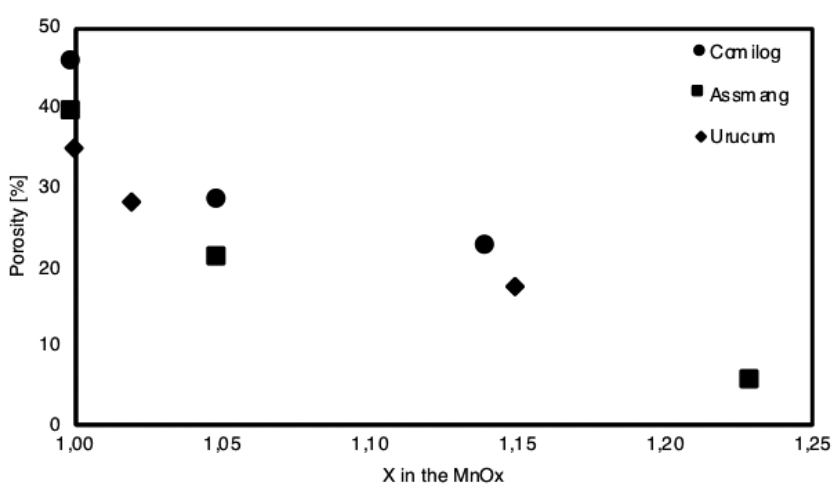

Fig. 7. Porosity versus the calculated $x$ in $\mathrm{MnO}_{\mathrm{x}}$ at $800^{\circ} \mathrm{C}$. decomposition.

The higher temperature increase noticed between $600^{\circ} \mathrm{C}$ and $800^{\circ} \mathrm{C}$ presented in the case of Comilog lumps and Comilog bentonite briquettes (Fig. 4) may also be explained by the lower porosity presented in such materials. The same characteristics were observed by Pochart et al. ${ }^{11)}$ which showed that materials whose interstitial space is lower presented higher increase due to the exothermic reactions.

The results of $\mathrm{CO}$ reactivity experiments are also plotted versus porosity in Fig. 7. It can be seen that a high porosity leads to high $\mathrm{CO}$ reactivity which leads to a lower oxygen content at $800^{\circ} \mathrm{C}$ which is accordance with other studies. ${ }^{3,13,14,18)}$ This is believed to be due to diffusion of $\mathrm{CO}$ in and $\mathrm{CO}_{2}$ out through the product layer being rate determining, which was observed by Berg and Olsen. ${ }^{12)}$

\section{Conclusions}

The work presented a comparative study on CO reactivity and porosity between lumps and briquettes with two different binder of three different raw materials. It was found that Comilog and Urucum materials have higher CO reactivity than Assmang. Through the work it was found that high porosity affects positively the $\mathrm{CO}$ reactivity which corroborates with previous works performed on the subject. As consequence, briquettes performed better than lumps of the same ore. The molasses decomposition enhances the porosity of molasses briquettes leaving them as the ones with higher reactivity when compared with lumps and bentonite briquettes.

\section{REFERENCES}

1) S. E. Olsen, M. Tangstad and T. Lindstad: Production of Manganese Ferroalloys, Tapir Academic Press, Trondheim, Norway, (2007), 28.

2) M. Tangstad: Ph.D. thesis, Norwegian Institute of Technology, (1996), https://bibsys-almaprimo.hosted.exlibrisgroup.com/permalink/ f/13q4kuj/BIBSYS_ILS71472669430002201 (accessed 2020-08-31).

3) K. Turkova, D. Slizovskiy and M. Tangstad: ISIJ Int., 54 (2014), 1204. https://doi.org/10.2355/isijinternational.54.1204

4) R. E. Hebeda: Syrups in Kirk-Othmer Encyclopedia of Chemical Technology, Wiley, Hoboken, NJ, (2000), 1083. https://doi.org/10.1002 0471238961.1925182108050205.a01

5) A. H. Weir and R. Greene-Kelly: Am. Mineral., 47 (1962), 137.

6) T. By: Master thesis, Norwegian Institute of Technology, (2017), http://hdl.handle.net/11250/2453618, (accessed 2020-08-31).

7) R. Kononov, O. Ostrovski and S. Ganguly: ISIJ Int., 49 (2009), 1107. https://doi.org/10.2355/isijinternational.49.1107

8) R. Kononov, O. Ostrovski and S. Ganguly: ISIJ Int., 49 (2009), 1115. https://doi.org/10.2355/isijinternational.49.1115

9) M. I. Zaki, M. A. Hasan, L. Pasupulety and K. Kumari: Thermochim. Acta, 311 (1998), 97. https://doi.org/10.1016/S0040-6031(97)00417-6

10) N. J. Welham: Int. J. Miner. Process., 67 (2002), 187. https://doi. org/10.1016/S0301-7516(02)00045-5

11) G. Pochart, L. Joncourt, N. Touchard and C. Perdon: Proc. 11th Int. Ferroalloys Cong., IFAPA, Mumbai, (2007), 217.

12) K. L. Berg and S. E. Olsen: Metall. Mater. Trans. B, 31 (2000), 477. https://doi.org/10.1007/s11663-000-0154-4

13) M. Tangstad, D. Leroy and E. Ringdalen: Proc. 12th Int. Ferroalloys Cong., Outotec Oyj, Esbo, (2010), 457.

14) M. Tangstad: Proc. Southern African Pyrometallurgy 2011 Int. Conf., SAIMM, Johannesburg, (2011), 209.

15) G. L. Faria, J. A. S. Tenório, N. Jannotti, Jr. and F. G. da S. Araújo: Int. J. Miner. Process., 137 (2015), 59. https://doi.org/10.1016/j. minpro.2015.03.003

16) R. S. Braga, C. Takano and M. B. Mourão: Ironmaking Steelmaking, 34 (2007), 279. https://doi.org/10.1179/174328107X155349

17) B. D. Flores, A. Guerrero, I. V. Flores, A. G. Borrego, M. A. Díez, E. Osório and A. C. F. Vilela: Fuel Process. Technol., 155 (2017), 238.

18) R. Elliott and M. Barati: Extraction 2018: Proc. 1st Global Conf. on Extractive Metallurgy, Springer, Cham, (2018), 1129. 